\title{
Consortium of eucalyptus with forage sorghum in semiarid of Minas Gerais State
}

\author{
Carlos Juliano Brant Albuquerque ${ }^{1^{*}}$ Sérgio Macedo Silva ${ }^{2}$ \\ José Magno Queiroz Luz ${ }^{2}$ César Henrique Zandonadi ${ }^{2}$
}

${ }^{1}$ Instituto de Ciências Agrárias (ICA), Universidade Federal de Minas Gerais (UFMG), 39404-547, Montes Claros, MG, Brasil. E-mail: carlosjuliano@ufmg.br. "Corresponding author.

${ }^{2}$ Instituto de Ciências Agrárias (ICA), Universidade Federal de Uberlândia (UFU), Uberlândia, MG, Brasil.

\begin{abstract}
The objective was to estimate the wood yield and essential oil content in three clones of eucalyptus that were planted in four contrasting arrangements and intercropped with sorghum. Eucalyptus clones MA2001 (Eucalyptus camaldulensis x E. tereticornis), A144 (Eucalyptus urophylla $x$ E. grandis), and GG100 (Eucalyptus urophylla $x$ E. grandis), were planted in single rows (10x2m), double rows $(2 \times 3+15 \mathrm{~m}$ and $2 \times 3+20 \mathrm{~m})$; and, triple rows $(2 \times 3 \times 2+10 \mathrm{~m})$ in a randomized, complete block design experiment with four replicates. Our results demonstrated that planting spacing did not influence the essential oil yield or diameter at breast height in the clones. However, higher density plantings were shown to result in higher fresh weight of branches and leaves per plant. MA2001 grew taller, produced higher quantity of fresh biomass of branches and leaves per plant and volume of wood per hectare, and yielded more essential oil yield than the other clones. We concluded that MA2001 is the most suitable of the clones tested here for cultivation in water deficit conditions.
\end{abstract}

Key words: row spacings, clones, forest, integrated crop-livestock-forestry system (ICLF).

Clones de eucalipto em consórcio com o sorgo forrageiro no semiárido de Minas Gerais

RESUMO: O objetivo do trabalho foi estimar o rendimento de madeira e o teor de óleo essencial de clones de eucalipto em diferentes arranjos, consorciado com sorgo. Foram utilizados 3 clones de eucalipto: Clone 1 (MA2001-Eucalyptus camaldulensis x E. tereticornis); Clone 2 (A144-Eucalyptus urophylla x E. grandis); Clone 3 (GG100 - Eucalyptus urophylla x E. grandis). Os clones de eucalipto foram plantados nos diferentes arranjos: em linha dupla, sendo $2 \times 3+15 \mathrm{~m}$ e $2 \times 3+20 \mathrm{~m}$; linhas simples $10 \times 2 \mathrm{~m}$ e em linha tripla, sendo $2 \times 3 \times 2+10 \mathrm{~m}$. $O$ delineamento experimental adotado foi o de blocos casualizados, com quatro repetições, sendo os tratamentos referentes a 3 clones de eucalipto e 4 arranjos de plantas diferentes. Os resultados mostraram que menores ou maiores espaçamentos não influenciaram no rendimento de óleo essencial e no diâmetro da altura do peito. Porém, menores espaçamentos podem proporcionar maior matéria fresca de ramos e folhas por planta. O clone MA2001 (Camaldulensis x Tereticornis) por ter apresentado maior altura de plantas, maior matéria fresca de galho e folhas por planta, maior volume de madeira por hectare e maior produtividade de óleo essencial pode ser o mais indicado para cultivo em condições com maior déficit hídrico.

Palavras-chave: espaçamentos, clones, florestal, integração lavoura-pecuária-floresta (iLPF).

\section{INTRODUCTION}

Integrated crop-livestock-forestry systems (ICLF), which support environmental conservation and restoration of degraded land, employ conservation practices with the main goal of producing food, fiber, and energy and cultivating wood and non-wood materials.

Several factors influenced the choice of tree species and forage crops used in ICLF systems, such as environmental suitability, market potential, and adaptation factors to the consortium of the crop (OLIVEIRA NETO \& PAIVA, 2010). The forest component of the ICLF systems should be managed to provide a balance with the other elements of the system and avoid possible conflicts between pasture and agriculture, for example, grass provides straw for no-till and agriculture provides residual fertilizer for pasture. (ALVARENGA et al., 2006).

Among the forest species in Brazil, eucalyptus are well adapted to the prevailing edaphoclimatic conditions and grow rapidly and are hence the main species cultivated for wood production in the country (HSING et al., 2016). It is also used in producing paper, cellulose, charcoal, ornaments and essential oil. 
Suitable spacing of forest tree species in planting rows is important for successful seedling establishment, especially in regions where the soil fertility is low and water availability is poor and irregular, such as in the semi-arid Minas Gerais region of Brazil (BERNARDO, 1995). In general, smaller row spacing of trees results in intense competition for resources, whereas larger spacing can result in underutilization of available resources and reduced productivity of the forest component of the ICLF system.

In addition to row spacing in ICLF systems, the number of plants per row determines the optimal planting arrangement to effectively exploit the available natural and supplemented resources. Planting density is determined by factors such as the purpose of using the product and the influence of initial spacing on biological variables (seedling survival rate, circumference, crown, quality and volume of wood, and essential oil yield) and operational variables (intensity of forestry management, soil preparation, forestry treatments, and harvesting) (SMITH \& STRUB, 1991). In particular, eucalyptus essential oils have several applications in the pharmaceutical, chemical, and cosmetic industries, and because of their economic significance, it is necessary to study their yield, which is the ratio between the amount of oil produced and the quantity of leaves distilled and understand the effect of planting density on yield.

Taller growth in trees has been observed with smaller spacing in forest monoculture systems (OLIVEIRA et al., 2009). Similarly, PEREIRA et al. (1983) reported the increased height in Eucalyptus grandis and attributed this to competition for light that would have stimulated plant growth. OLIVEIRA et al. (2015) observed that when cultivated in $3 \mathrm{~m} \times 2 \mathrm{~m}$ plots, eucalyptus trees grown in the ICLF system were taller and had greater diameter at breast height than those cultivated in monoculture. KRUSCHEWKY et al. (2007) reported similar results, wherein plant height was higher in denser eucalyptus planting arrangements in the Brazilian's "cerrado" region.

Designing planting schemes for optimized productivity in ICLF systems is essential in the drive for sustainable agriculture. Therefore, the objective of this research was to estimate the yield of wood and essential oil content of eucalypt clones grown in different configurations and densities and intercropped with sorghum, in the semi-arid region of Minas Gerais, Brazil.

\section{MATERIALS AND METHODS}

The experiment began in August 2012 and was carried out at Bonsucesso Farm, Francisco

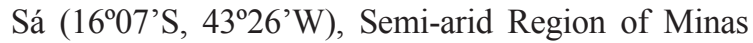

Gerais, at $591 \mathrm{~m}$ above sea level, where the predominant climate is Aw (Köppen), with a dry season, average annual temperature of $22.3^{\circ} \mathrm{C}$. The average annual rainfall is $981 \mathrm{~mm}$ which mostly occurs from October to March (CLIMATE-data.org, 2016).

The experiment comprised a complete randomized $3 \times 4$ factorial block design, with four replicates. The factors were three eucalyptus clones and plots with four different spatial planting arrangements with trees planted in single row (one tree), double rows (two parallel trees), and triple rows (three parallel trees).

We used three eucalyptus clones: Clone 1 (MA2001: Eucalyptus camaldulensis x E. tereticornis); Clone 2 (A144: Eucalyptus urophylla x E. grandis); and, Clone 3 (GG100: Eucalyptus urophylla $\mathrm{x}$ E. grandis). Clones were transplanted in single rows at $10 \times 2 \mathrm{~m}$; double rows at $2 \times 3+15 \mathrm{~m}$ and $2 \times 3+20 \mathrm{~m}$; and, triple rows at $2 \times 3 \times 2+10 \mathrm{~m}$.

Soil samples from three depths $(0-20 \mathrm{~cm}$, $20-40 \mathrm{~cm}$, and $40-60 \mathrm{~cm}$ ) were taken from the area for analysis, and the results are presented in table 1 . Soil acidity was adjusted by applying $1000 \mathrm{~kg} \mathrm{ha}^{-1}$ of Agrosilicon S, containing calcium (19.6\%), magnesium (4.2\%), sulfur (5\%) and silicon (7.3\%).

Table 1 - Properties of soil samples taken from depths of 0 $20 \mathrm{~cm} ; 20-40 \mathrm{~cm} ; 40-60 \mathrm{~cm}$ at the experimental site.

\begin{tabular}{|c|c|c|c|}
\hline \multirow[t]{2}{*}{ Soil atributes } & \multicolumn{3}{|c|}{--------------------Depth----------------- } \\
\hline & $0-20 \mathrm{~cm}$ & $20-40 \mathrm{~cm}$ & $40-60 \mathrm{~cm}$ \\
\hline $\mathrm{pH} \mathrm{em} \mathrm{H}_{2} \mathrm{O}$ & 5.1 & 5.0 & 5.3 \\
\hline $\mathrm{H}+\mathrm{Al}\left(\mathrm{cmolc} \mathrm{dm}^{-3}\right)$ & 4.3 & 4.3 & 3.1 \\
\hline $\mathrm{Al}\left(\mathrm{cmolc} \mathrm{dm}^{-3}\right)$ & 0.6 & 0.8 & 0.4 \\
\hline $\mathrm{Ca}\left(\mathrm{cmolc} \mathrm{dm}^{-3}\right)$ & 3.3 & 3.9 & 4.9 \\
\hline $\operatorname{Mg}\left(\mathrm{cmolc} \mathrm{dm}^{-3}\right)$ & 1.5 & 1.5 & 1.7 \\
\hline $\mathrm{K}\left(\mathrm{mg} \mathrm{dm} \mathrm{m}^{-3}\right)$ & 100 & 52 & 58 \\
\hline $\mathrm{P}\left(\mathrm{mg} \mathrm{dm}^{-3}\right)$ & 3.7 & 2.3 & 2.3 \\
\hline $\mathrm{Zn}\left(\mathrm{mg} \mathrm{dm}^{-3}\right)$ & 1.7 & 1.6 & 1.9 \\
\hline $\mathrm{Fe}\left(\mathrm{mg} \mathrm{dm}^{-3}\right)$ & 45.7 & 45.9 & 40.7 \\
\hline $\operatorname{Mn}\left(\mathrm{mg} \mathrm{dm}^{-3}\right)$ & 32.4 & 24.9 & 27.7 \\
\hline $\mathrm{Cu}\left(\mathrm{mg} \mathrm{dm}^{-3}\right)$ & 3.2 & 3.3 & 3.2 \\
\hline $\mathrm{B}\left(\mathrm{mg} \mathrm{dm}^{-3}\right)$ & 0.6 & 0.6 & 0.5 \\
\hline $\mathrm{SB}\left(\mathrm{cmolc} \mathrm{dm}^{-3}\right)$ & 5.2 & 5.6 & 6.8 \\
\hline $\mathrm{T}\left(\mathrm{cmolc} \mathrm{dm}^{-3}\right)$ & 9.5 & 9.9 & 9.9 \\
\hline $\mathrm{t}\left(\mathrm{cmolc} \mathrm{dm}^{-3}\right)$ & 5.8 & 6.4 & 7.2 \\
\hline V $(\%)$ & 55 & 57 & 69 \\
\hline m (\%) & 10 & 12 & 6 \\
\hline sand $\left(\right.$ dag kg $\left.{ }^{-1}\right)$ & 16 & 15 & 16 \\
\hline Silt $\left(\right.$ dag kg $\left.{ }^{-1}\right)$ & 16 & 21 & 25 \\
\hline Clay (dag kg ${ }^{-1}$ ) & 68 & 64 & 59 \\
\hline
\end{tabular}


In August 2012, the planting area was subsoiled, and then $40 \mathrm{~cm}$ deep furrows were plowed in an east-west direction, to which $150 \mathrm{~g} \mathrm{~m}^{-1}$ of reactive phosphate was added. A sub soiler with three rods was used for deeper incorporation of fertilizer and to close the center of the furrows. Fertilization of the seedlings $\left(240 \mathrm{~g} \mathrm{~m}^{-1}\right.$ compost fertilizer NPK 0828-16) was done through lateral furrows.

Eucalyptus seedling clones were bred from nursery plants accredited by the Ministry of Agriculture and Livestock (MAPA) and raised in $50 \mathrm{~cm}^{3}$ polypropylene tubes containing organic substrate. In September 2012, when the seedlings were $25 \mathrm{~cm}$ tall, the seedlings were soaked in $20 \mathrm{~g} \mathrm{~L}^{-1}$ phosphorus fertilizer solution and planted in the experimental plots. Irrigation was performed daily, where $4 \mathrm{~L}$ water per seedling was supplied from a water tank coupled to a tractor. To increase water retention around the seedlings, $1 \mathrm{~kg}$ Hydroplan-EB polymerized gel per $100 \mathrm{~L}$ water was applied, and the gel covered about $80 \%$ of the seedlings, encircling each for approximately $2 \mathrm{~cm}$. The experimental plots managed for pests, such as leaf cutting ants, using Fipronil-based formicide baits.

Irrigation ceased with the onset of the rainy season in November 2012, and the herbicide isoxaflutol (750 $\mathrm{g} \mathrm{kg}^{-1}$, dispersible granulate) was applied to control weeds such as Brachiaria plantaginea.

Number of trees per hectare and clones in the different planting arrangements at the start and end of the experiment are presented in table 2. After re-grading between the lines of eucalyptus, sorghum was drilled in each of the four different eucalyptus spatial planting arrangements during the two harvests of 2012-2013 and 2013-2014. A cultivar of Sorghum with great grain production and forage mass potential (cv. "BRS 655") was drilled $70 \mathrm{~cm}$ between rows and $10 \mathrm{~cm}$ between eucalyptus plants and was fertilized with $400 \mathrm{~kg} \mathrm{ha}^{-1}$ NPK (04-30-10). Sorghum was drilled $1 \mathrm{~m}$ away from the eucalyptus lines to facilitate agronomic practice and to reduce likely competitive effects of the trees for resources. When the sorghum plants presented five fully expanded leaves (complete exposition of the sheath), $200 \mathrm{~kg} \mathrm{ha}^{-1}$ of compost fertilizer NPK 20-00-20 was applied.

The agronomic characteristics of the eucalyptus trees were measured 12 months after planting and 90 days after the 2013-2014 sorghum crops were harvested: plant height (total and average) and circumference at chest height (CAP) were measured, and diameter at chest height (DAP) was calculated, thus: $\mathrm{DAP}=\mathrm{CAP} \times \pi^{-1}$.

The mean DAP of each plot was obtained from the mean of the DAP of seedlings in the same plot. Finally, the mortality rate of eucalyptus plants was also evaluated.

On July 18, 2014, a day without rainfall, two-thirds of the branches and leaves in the plots were felled using a sickle and saw and weighed to calculate fresh biomass per plant and fresh biomass per hectare. Then, approximately $500 \mathrm{~g}$ of the fresh

Table 2 - Growth characteristics of eucalyptus clones in experimental plots of different planting arrangements.

\begin{tabular}{|c|c|c|c|c|c|c|}
\hline Clone & Arrangement & Plants Iniciais & Plants Finais & DAP & A & Mortality \\
\hline \multirow{4}{*}{ MA2001 } & $2 \times 3+(15 m)$ & 555 & 552.23 & \multirow{4}{*}{2.67} & \multirow{4}{*}{2.56} & \multirow{4}{*}{0.50} \\
\hline & $2 \times 3+(20 m)$ & 434 & 431.83 & & & \\
\hline & $2 \times 10 \mathrm{~m}$ & 500 & 497.50 & & & \\
\hline & $2 \times 3 \times 2+(10 \mathrm{~m})$ & 938 & 933.31 & & & \\
\hline \multirow{4}{*}{ A144 } & $2 \times 3+(15 \mathrm{~m})$ & 555 & 457.88 & \multirow{4}{*}{3.63} & \multirow{4}{*}{2.12} & \multirow{4}{*}{17.50} \\
\hline & $2 \times 3+(20 m)$ & 434 & 358.05 & & & \\
\hline & $2 \times 10 \mathrm{~m}$ & 500 & 412.50 & & & \\
\hline & $2 \times 3 \times 2+(10 \mathrm{~m})$ & 938 & 773.85 & & & \\
\hline \multirow{4}{*}{ GG100 } & $2 \times 3+(15 \mathrm{~m})$ & 555 & 480.63 & \multirow{4}{*}{5.86} & \multirow{4}{*}{1.79} & \multirow{4}{*}{13.40} \\
\hline & $2 \times 3+(20 m)$ & 434 & 375.84 & & & \\
\hline & $2 \times 10 \mathrm{~m}$ & 500 & 433.00 & & & \\
\hline & $2 \times 3 \times 2+(10 \mathrm{~m})$ & 938 & 812.31 & & & \\
\hline
\end{tabular}

Mean number of plants at planting (Initial) and final count (Final), mean diameter at chest height (DAP), mean plant height (A) and mortality $(\%)$ of plants. 
leaf samples was packed in a plastic bag and shipped to the laboratory in a styrofoam box containing ice for essential oil extraction.

The extraction of essential oil from the eucalyptus leaves was carried out in the Laboratory of Phytotechnology of the Universidade Federal de Uberlândia (UFU), by hydrodistillation, using modified Clevenger-type apparatus. Samples of fresh leaves $(120 \mathrm{~g})$ were placed in flasks containing $1500 \mathrm{~mL}$ of distilled water for a period of $2 \mathrm{~h}$, after which time the hydrolate was centrifuged in a horizontal crosshead centrifuge (radius $=5 \mathrm{~cm}$ ) at 4,500rpm for 60s, following CASTRO et al. (2005). Essential oil yield was calculated and expressed as oil volume per dry weight of leaves $(\% \mathrm{v} / \mathrm{w})$ (PIMENTEL et al., 2006) and essential oil yield per hectare $\left(\mathrm{g} \mathrm{ha}^{-1}\right)$ was then calculated by extrapolating the volume of oil obtained in each leaf sample to the production per plot area.

Normality of the data was tested for using the Shapiro-Wilk test, homogeneity of variance was estimated using by Levene's test, and block additivity was assessed by Tukey's F-test of Tukey, at a 0.01 significance level; all tested were done using SPSS Statistical Software, version 17.0 (SPSS Inc., Chicago, IL, USA). Plot averages were compared using analysis of variance (ANOVA, $\mathrm{P}<0.05$ ) and when applicable, means $( \pm \mathrm{SE})$ were separated by
Scott Knott test $(\mathrm{P}<0.05)$ using the statistical program ASSISTAT 7.7 beta (SILVA, 2009).

\section{RESULTS AND DISCUSSION}

In general, plant height and fresh biomass of branches and leaf per plant significantly differed among the different clones. There were significant interactions between types of spatial planting configuration and CAP and fresh biomass of branches and leaves per hectare $(\mathrm{P}<0.05)$ of the clones (Table 3$)$.

Plant height was greatest in clone MA2001 and least in clone GG100, while fresh branch and leaf biomass per plant was greatest in clones MA2001 and A144 (Table 3).

We reported that CAP of clone A144 differed among the planting configurations, whereas that of the other clones was unaffected. The largest CAP for clone A144 was observed in the $2 \times 3+(15 \mathrm{~m})$ and $2 \times 3+(20 \mathrm{~m})$ plots. Clone MA2001 had the highest $\mathrm{CAP}$, independent of planting arrangement, which was not statistically different from that of clone A144 in the $2 \times 3+(15 \mathrm{~m})$ and $2 \times 3+(20 \mathrm{~m})$ plots or clone GG100 in the $2 \times 10 \mathrm{~m}$ and $2 \times 3 \times 2+(10 \mathrm{~m})$ plots.

Eucalyptus planting arrangements only affected fresh biomass of branches and leaves per hectare in clone GG100 clone, where fresh biomass was greatest in the $2 \times 3+(20 \mathrm{~m})$ plots. Fresh biomass

Table 3 - Height of plants (A), fresh biomass of branches and leaves per plant (MF), circumference at chest height (CAP) and fresh biomass of branches and leaves per hectare (MF) of different eucalyptus clones.

\begin{tabular}{|c|c|c|c|c|}
\hline Clone & \multicolumn{2}{|c|}{$\mathrm{HP}(\mathrm{m})$} & \multicolumn{2}{|c|}{$\mathrm{MF}(\mathrm{kg})$} \\
\hline MA2001 & \multicolumn{2}{|c|}{$9.03 \mathrm{~A}$} & \multicolumn{2}{|c|}{$11.77 \mathrm{~A}$} \\
\hline A144 & \multicolumn{2}{|c|}{$7.26 \mathrm{~B}$} & \multicolumn{2}{|c|}{$11.75 \mathrm{~A}$} \\
\hline GG100 & \multicolumn{2}{|c|}{$6.16 \mathrm{C}$} & \multicolumn{2}{|c|}{$7.04 \mathrm{~B}$} \\
\hline \multirow[t]{3}{*}{$\mathrm{CV}(\%)$} & \multicolumn{2}{|c|}{12.90} & \multicolumn{2}{|c|}{34.44} \\
\hline & \multicolumn{4}{|c|}{ 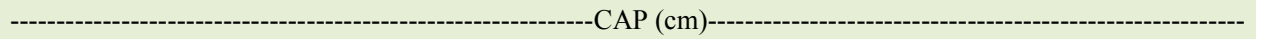 } \\
\hline & $2 \times 3+(15 \mathrm{~m})$ & $2 \times 3+(20 \mathrm{~m})$ & $2 \times 10 \mathrm{~m}$ & $2 \times 3 \times 2+(10 \mathrm{~m})$ \\
\hline MA2001 & $29.43 \mathrm{aA}$ & $29.00 \mathrm{aA}$ & $30.62 \mathrm{aA}$ & $30.88 \mathrm{aA}$ \\
\hline A144 & $29.13 \mathrm{aA}$ & $30,00 \mathrm{aA}$ & $21.00 \mathrm{bB}$ & $20.00 \mathrm{bB}$ \\
\hline GG100 & $21.13 \mathrm{bA}$ & $16.17 \mathrm{bA}$ & $18.31 \mathrm{bA}$ & $22.32 \mathrm{bA}$ \\
\hline \multirow[t]{2}{*}{$\mathrm{CV}(\%)$} & \multicolumn{4}{|c|}{16.04} \\
\hline & \multicolumn{4}{|c|}{ 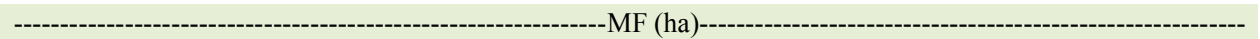 } \\
\hline A2001 & $15296.63 \mathrm{aA}$ & $12576.92 \mathrm{aA}$ & $9843.42 \mathrm{aA}$ & $11173.60 \mathrm{aA}$ \\
\hline A144 & $7062.54 \mathrm{bA}$ & $8951.25 \mathrm{bA}$ & $5094,38 \mathrm{bA}$ & $5068.60 \mathrm{bA}$ \\
\hline GG100 & $4541.09 \mathrm{bC}$ & $17616.93 \mathrm{aA}$ & $11758.16 \mathrm{aB}$ & $13658.96 \mathrm{aB}$ \\
\hline CV $(\%)$ & \multicolumn{4}{|c|}{29.27} \\
\hline
\end{tabular}

Means followed by distinct letters, lowercase in column and uppercase in row, differ by Scott-Knott's test at 0.05 significance. 
of clones MA2001 and GG100 was higher than that of the other clones, regardless of arrangement.

We found that volume of wood per hectare was greater in clone MA2001 compared with the other clones, due to the lower plant mortality. BOTELHO (1998) and OLIVEIRA NETO et al. (2003) showed a higher production of wood per unit area at greater planting densities because of the larger number of individuals, and similarly, FERREIRA et al. (2012) noted the positive influence of planting density on wood yield, as they reported higher productivity for more densely packed trees $(14 \times 2)$ than less dense plantings (22x2).

According to OLIVEIRA NETO et al. (2003), planting arrangement should reflect the intended use of the end product, since low density tends to increase the production of dry matter of the aerial parts and wood per tree, because of greater CAP. For higher density plantings, there is greater biomass production per unit area, due to the greater number of individuals, however, the diameter of the wood tends to be smaller, thus leading to another market.

Clone type, and not planting arrangement, affected essential oil yield per plant, and there was no significant interaction between these factors on essential oil yield (Table 4). We found that the lowest oil yield per plant was observed in the $2 \times 3 \times 2+(10 \mathrm{~m})$ plots, where values ranged from 2.93 to $6.59 \mathrm{~g}$ per plant. These results are similar to those observed by VITTI \& BRITO (2003), who also reported tree planting density effects on the production of essential oils in eucalyptus.

The clones MA2001 and GG100 yielded the highest amounts of essential oil per plant and per

Table 4 - Produtividade de óleo essencial em função de diferentes arranjos espaciais e clones de eucalipto.

\begin{tabular}{lcc}
\hline Arranjosarrangements & \multicolumn{2}{c}{ Rendimento yield (g per plant) } \\
\hline $2 \times 3+(15 \mathrm{~m})$ & \multicolumn{2}{c}{$6.18 \mathrm{~A}$} \\
$2 \times 3+(20 \mathrm{~m})$ & $6.36 \mathrm{~A}$ \\
$2 \times 10 \mathrm{~m}$ & \multicolumn{2}{c}{$6.59 \mathrm{~A}$} \\
$2 \times 3 \times 2+(10 \mathrm{~m})$ & $2.93 \mathrm{~B}$ \\
CV $(\%)$ & 44.07 \\
Clone & yield & Rendimento \\
& (g per plant) & (g ha $\left.{ }^{-1}\right)$ \\
MA2001 & $5.65 \mathrm{~A}$ & $3135.32 \mathrm{~A}$ \\
A144 & $4.12 \mathrm{~B}$ & $1937.68 \mathrm{~B}$ \\
GG100 & $6.78 \mathrm{~A}$ & $3189.06 \mathrm{~A}$ \\
CV $(\%)$ & 44.07 & 45.22 \\
\hline
\end{tabular}

Means followed by distinct letters differ by the Scott-Knott test at 0.05 significance. hectare. Interestingly, even clone GG100 showed good oil yield per hectare despite plant mortality.

In general and compared with the other clones, clone MA2001 (Eucalyptus camaldulensis x E. teneticornis) showed greater plant height, similar DAP, and lower plant mortality (Table 2). The performance of Eucalyptus camaldulensis may be due to adaptations such as greater efficiency in stomatal control and deeper root system, allowing growth in environments with considerable water deficit (LELES et al., 1998). These traits could benefit sorghum cultivation in environments where low luminosity and greater competition for nutrients and water create less favorable conditions for cereal cultivation.

\section{CONCLUSION}

Eucalyptus planting density does not influence essential oil yield and CAP; however, dense planting can provide greater fresh biomass of branches and leaves per plant. The clone MA2001 grew taller and produced more fresh leaf biomass, a higher volume of wood per hectare and higher yield of essential oil than the other clones. We suggested that it is the most suitable of the clones tested here for cultivation under conditions with a high water deficit.

\section{ACKNOWLEDGMENTS}

The authors thank Pró Reitoria de Pesquisa da Universidade Federal de Minas Gerais (UFMG), Fundação de Amparo a Pesquisa de Minas Gerais (FAPEMIG), Conselho Nacional de Desenvolvimento Científico e Tecnológico (CNPq), and Coordenação de Aperfeiçoamento de Pessoal de Nível Superior (CAPES) for their financial support.

\section{REFERENCES}

ALBUQUERQUE, C.J.B. et al. Extração de macronutrientes no sorgo granífero em diferentes arranjos de plantas. Revista Brasileira de Milho e Sorgo, v.12, n.1, p.10-20, 2013.

ALVARENGA, R.C. et al. A cultura do milho na Integração Lavoura-Pecuária. Sete Lagoas: Embrapa, 2006. 12p.

BERNARDO, A.L. Crescimento e eficiência nutricional de Eucalyptus spp. sob diferentes espaçamentos na região de cerrado de Minas Gerais. 1995. 102f. Dissertação (Mestrado em Ciência Florestal) - Universidade Federal de Viçosa, Viçosa, MG.

BOTELHO, S.A. Espaçamento. In: SCOLFORO, J.R.S. Manejo florestal. Lavras: UFLA/FAEPE, 1998. p.381-406.

CASTRO, N.E.A. et al. Avaliação de métodos de obtenção de óleo essencial de Eucalyptus. In: SIMPÓSIO BRASILEIRO DE ÓLEOS ESSENCIAIS, 3., 2005, Campinas, SP. Anais... Campinas: IAC, 2005. 
CLIMATE-DATA.ORG. Clima: Francisco de sá. Available from: $<$ http://pt.climate-data.org/location/24949/>. Accessed: Apr. 18, 2016.

FERREIRA, A.D. et al. Arranjos espaciais sobre a produtividade e o potencial de prestação de serviços ambientais do eucalipto em sistemas integrados. In: CONGRESSO LATINOAMERICANO DE SISTEMAS AGROFLORESTAIS PARA A PRODUÇÃO PECUÁRIA SUSTENTÁVEL, 7, 2012, Belém do Pará. Anais... Belém: editora ou entidade?, 2012 p. 5.

HSING, T.Y. et al. Características dendrométricas, químicas e densidade básica da madeira de híbridos de Eucalyptus grandis X Eucalyptus urophylla. Ciência Florestal, v.26, n.1, p.273-283, 2016.

KRUSCHEWSKY, G.C. et al. Arranjo estrutural e dinâmica de crescimento de Eucalyptus spp. em sistema agrossilvipastoril no Cerrado. Cerne, v.13, n.4, p.360-367, 2007.

LELES, P.S.S. et al. Relações hídricas e crescimento de árvores de Eucalyptus camaldulensis e Eucalyptus pellita sob diferentes espaçamentos na região de cerrado. Revista Árvore, v.22, n.1, p.41-50, 1998.

OLIVEIRA NETO, S.N. de; PAIVA, H.N. Implantação e manejo do componente arbóreo em Sistema Agrossilvipastoril. In: OLIVEIRANETO, S.N. de et al. (Org.). SISTEMAAGROSSILVIPASTORIL - Integração lavoura, pecuária e floresta. Viçosa, MG: Arka, 2010. V.01, p.15-68.
OLIVEIRA NETO, S.N. et al. Produção e distribuição de biomassa em Eucalyptus camaldulensis Dehn. em resposta à adubação e ao espaçamento. Revista Àrvore, v.27, n.1, p.15-23, 2003.

OLIVEIRA, F.L.R. de, et al. Crescimento inicial de eucalipto e acácia, em diferentes arranjos de integração lavoura-pecuáriafloresta. Cerne, v.21, n.2, p.227-233, 2015.

OLIVEIRA, T.K. et al. Desempenho silvicultural e produtivo de eucalipto sob diferentes arranjos espaciais em sistema agrossilvipastoril. Pesquisa Florestal Brasileira, n.60, p.1-9, 2009.

PIMENTEL, F.A. et al. A convenient method for the determination of moisture in aromatic plants. Química Nova, v.29, n.2, p.373-375, 2006.

SILVA, F.A.S.E.; AZEVEDO, C.A.V. de. Principal components analysis in the software assistat-statistical assistance. In: WORLD CONGRESS ON COMPUTERS IN AGRICULTURE, 7., 2009, Reno. Proceedings... St. Joseph: ASABE, 2009. CD-Rom. p.1-5.

SMITH, W.D.; STRUB, M.R. Initial spacing: how many trees to plant. In: DUREYA, M.L.; DOUGHERTY, P.M. (Eds.). Forest regeneration manual. Netherlands: Kluwer Academic Publishers, 1991. p.281-289.

VITTI, A.M.S.; BRITO, J.O. Óleo essencial de eucalipto. Piracicaba: ESALQ-USP, 2003. (Documentos Florestais, n.17). 